\title{
Effect of Different Levels of Rice Gluten Meal with and without Enzyme Supplementation on Duodenal Morphology of Broilers
}

\author{
Lakhvir Singh, Udeybir Singh*, Devendra Pathak, J.S. Lamba and A.P.S. Sethi \\ Department of Animal Nutrition, Guru Angad Dev Veterinary and Animal Sciences University, Ludhiana, Punjab, INDIA \\ "Corresponding author: U Singh E-mail: udeybirchahal@gmail.com
}

Received: 28 Sept., 2020

Revised: 17 Oct., 2020

Accepted: 13 Nov., 2020

\begin{abstract}
Rice Gluten Meal availability is more, and it is also a low-cost feed source that can be used as substitute for protein sources in broiler diets. Present study evaluated the effects of dietary supplementation of rice gluten meal (RGM) with and without enzyme on duodenal morphology. 240-day-old broiler chicks were randomly allocated to six groups with four replicates. During this experiment starter, grower and finisher period, experimental diets were fed to birds which were isonitrogenous and isocaloric formulated with different levels of RGM. They were $\mathrm{T}_{1}$ (control, without RGM and enzyme), $\mathrm{T}_{2}$ (control, without RGM and with cocktail of enzyme @100g/q feed), $\mathrm{T}_{3}\left(10 \%\right.$ RGM), $\mathrm{T}_{4}$ (10\% RGM with cocktail of enzyme @ $100 \mathrm{~g} / \mathrm{q}$ feed), $\mathrm{T}_{5}(15 \%$ RGM), $\mathrm{T}_{6}\left(15 \%\right.$ RGM with cocktail of enzyme @ $100 \mathrm{~g} / \mathrm{q}$ feed). The birds of equal body weight were slaughtered on $42^{\text {nd }}$ day. After thorough examination sections of duodenum were collected and processed for histomorphology. Images were taken to measure villi height and crypt depth. The present study showed the villus height was greater in the duodenum while there was a tendency for increased villus height to crypt depth ratio in the duodenum of broilers supplemented with $15 \%$ rice gluten meal. These results indicated that rice gluten meal enhanced the villus development in the small intestine of broilers.
\end{abstract}

\section{HIGHLIGHTS}

0 Effect of rice gluten meal and enzyme supplementation on gut morphology of broilers was studied.

(O Rice gluten meal enhanced the villus development in the small intestine of broilers.

Keywords: Rice gluten meal, broilers, duodenal morphology, villi height, crypt depth

Good nutrition management is one of the important bases for healthy and economical rearing of poultry as there is a positive relation between nutrition, health and growth performance. With the increasing human population and income sources the demand for animal products is also increasing day by day. Poultry industry is one of the major industries that are supporting the vast population of the world. To meet the meat demand of increasing human population no doubt genetic makeup, feeding and managemental practices, disease prevention etc. are the main factors but major concern is to reduce feed cost for optimal economic returns because the feed constitutes approximately $70 \%$ of the total production cost. So there is an urgent need toexplore the various agroindustrial waste and other unconventional feed resources for an economically viable poultry production (Bhatt and Sharma, 2001).

As there is scarcity of both maize and soybean at reasonable price, there is need to utilize locally available feed ingredients. India is one of the largest producers of rice in world producing approximately 112.91 million tons of rice and Punjab produces 11.85 million tons of rice in 2017-18 (GOI, 2018). So, a lot of by-products are available from rice processing industry. Among the various by-products of rice, rice gluten meal (RGM) is a protein by-product

How to cite this article: Singh, L., Singh, U., Pathak, D., Lamba, J.S. and Sethi, A.P.S. (2020). Effect of different levels of rice gluten meal with and without enzyme supplementation on duodenal morphology of broilers. J. Anim. Res., 10(6): 917-923.

Source of Support: None; Conflict of Interest: None

क 9 
that have the potential to be incorporated in livestock and poultry feed. Rice gluten meal (RGM) is the dried residue from rice after the removal of starch and separation of the bran by the wet milling process. Rice gluten meal is rich in crude protein $(46 \%)$ and has $3152 \mathrm{kcal} / \mathrm{kg}$ metabolizable energy (Kumar et al., 2016). Based on feed cost, rice gluten meal could be an effective alternative feed ingredient in the diet of broilers. If diets can be formulated using this ingredient, farmers will be able to pay less for their feed, hence reducing their overhead cost. Very first research on RGM conducted by Sherazi et al. (1995) showed that RGM can be included up to $10 \%$ level in broiler chicken without affecting feed efficiency and dressing percentage. Metwally and Farahat (2015) found in their research that broiler fed with RGM at different inclusion rates up to $12.5 \%$ had almost same growth performance, carcass traits and serological parameters.

There is very little literature and only a few researches are available regarding effect of rice gluten meal (RGM) on gut morphology in broilers. So, there is need to evaluate RGM effect on gut morphology in broilers for safe inclusion level of RGM in broiler diets as RGM availability is more and it is also a low cost feed source that can be used as substitute for protein sources in broiler diets.

\section{MATERIALS AND METHODS}

42 days feeding trial was conducted on 240 sexed chicks which were weighed individually at 1 day of age and distributed randomly into 6 treatments having total 10 birds per treatment with 4 replicates. The treatments were $\mathrm{T}_{1}$ (control, without RGM and enzyme), $\mathrm{T}_{2}$ (control, without RGM and with cocktail of enzyme @100g/q feed), $\mathrm{T}_{3}(10 \% \mathrm{RGM}), \mathrm{T}_{4}(10 \% \mathrm{RGM}$ with cocktail of enzyme @100g/q feed), T (15\% RGM), T 6 (15\% RGM with cocktail of enzyme @ $100 \mathrm{~g} / \mathrm{q}$ feed). At the end of experiment i.e. on $42^{\text {nd }}$ days, one bird /replicate making four birds per treatments with equal sex ratio and identical body weight were sacrificed. Dressing was done and after thorough gross examination, small representative pieces (approximately $0.5 \mathrm{~cm}$ length) of duodenum and liver were collected from each sacrificed bird and fixed in $10 \%$ neutral buffered formalin.

After fixation for 2 days, tissues were cut into smaller sections (1-2 mm thick). The tissues were washed in running water for overnight, dehydrated in ascending grades of ethyl alcohol and acetone. Dehydrated tissue samples were cleared in benzene and embedded in paraffin wax (Pathak and Bansal 2012). The paraffin blocks prepared were cut at 4-5 $\mu$ thickness sections with a hand operated microtome. The paraffin embedded sections were then passed through sequential steps of deparaffinization in xylene, rehydration through descending grades of ethyl alcohol to running water. Sections were stained by routine haematoxylin and eosin stain.

\section{Microphotography and histometry}

Stained sections were examined and photographed (10 images per slide per bird) using a light microscope (Nikon $80 \mathrm{i})$ attached with a digital camera. For each section, 6-10 photomicrographs were captured at 400-magnification (40× objective lens). Images were processed and histometrical measurements of duodenum viz. Villi height and Crypt depth Fiji (ImageJ) software (Schindelin et al. 2012). The collected data were analyzed using software package for social sciences (SPSS Version 24.0) at 95\% significant level using Tukey's-b level of significance values.

\section{RESULTS AND DISCUSSION}

The tunica mucosa of duodenum of control birds $\left(\mathrm{T}_{1}\right)$ was seen as slender, unbranched longitudinal projections termed as villi. The tips of the villi were conical in shape (Fig. 1A). The lamina propria mucosae comprised of loose connective tissue while the muscularis mucosa was marked by longitudinally arranged smooth muscle fibers towards the side of the submucosa and vertically arranged smooth muscle fiber strands on the side of the lamina Propria. The villi of the duodenum were lined by simple columnar epithelium. The columnar cells had elongated nuclei (Fig. 1B). The epithelium comprised of multiple cell types i.e. the chief cells, goblet cells and the enterochromaffin cells. Few polymorphonuclear cells were also observed at places in mucosa. Similar observations were recorded by Nasrin et al. (2012) in broilers and Rana et al. (2016) in Uttara fowl. The average length of villi was $1038.11 \mu \mathrm{m}$ and average depth of crypt was $1027.32 \mu \mathrm{m}$ (Table 1) shows normal morphology of duodenum which was visible in the Fig. 1(A).

Mucosa of duodenum of birds fed with feed supplemented with enzymes $\left(\mathrm{T}_{2}\right)$ was thrown in finger like longitudinal 
Table 1: Effect of feeding different levels of RGM on the duodenal morphologyin broilers

\begin{tabular}{lllllllll}
\hline Variables & $\mathbf{T}_{1}$ & $\mathbf{T}_{2}$ & $\mathbf{T}_{3}$ & $\mathbf{T}_{4}$ & $\mathbf{T}_{\mathbf{5}}$ & $\mathbf{T}_{\mathbf{6}}$ & S.E.M. & P Value \\
\hline Villi Height & $1038.11^{\mathrm{a}}$ & $1575.33^{\mathrm{bc}}$ & $1413.13^{\mathrm{b}}$ & $1647.44^{\mathrm{bcd}}$ & $1985.66^{\mathrm{d}}$ & $1873.99^{\text {cd }}$ & 62.09 & $\leq 0.05$ \\
Crypt Depth & $1027.32^{\mathrm{a}}$ & $1405.34^{\mathrm{c}}$ & $1089.71^{\mathrm{ab}}$ & $1128.80^{\mathrm{ab}}$ & $1356.30^{\mathrm{bc}}$ & $1729.44^{\mathrm{d}}$ & 48.23 & $\leq 0.05$ \\
Ratio $(\mathrm{VH} / \mathrm{CD})$ & $1.01^{\mathrm{a}}$ & $1.13^{\mathrm{b}}$ & $1.33^{\mathrm{ab}}$ & $1.57^{\mathrm{ab}}$ & $1.46^{\mathrm{ab}}$ & $1.08^{\mathrm{ab}}$ & 0.05 & $\leq 0.05$ \\
\hline
\end{tabular}
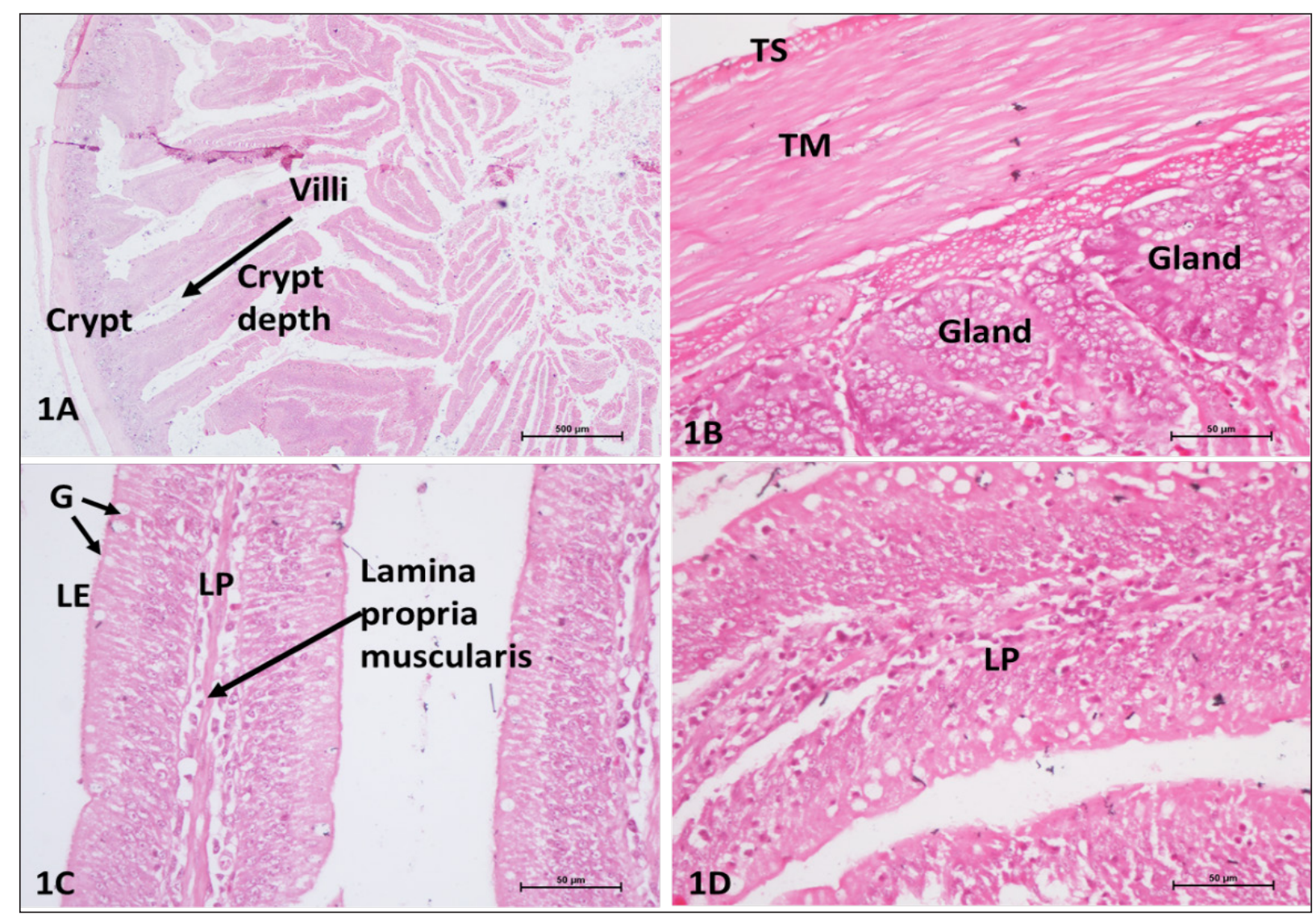

Fig. 1: Paraffin section of duodenum of control $\left(\mathrm{T}_{1}\right.$ and $\left.\mathrm{T}_{2}\right)$ birds showing duodenal villi, crypt and crypt depth, (1A); glands in crypt, tunica mucosa (TM) and tunica serosa (TS) (1B); Lamina epithelialis (LE), Lamina propria muscularis in Lamina propria (LP) and Goblet cells (G) (1.C); Lamina propria (LP); Haematoxylin and eosin: Bar length (A) $500 \mu \mathrm{m}$ (B), (C) and (D) $50 \mu \mathrm{m}$

villi similar to the above control group birds (Fig. 1A). The villi were broader near the base and conical at the apex. The lamina Propria was consisted of loose connective tissue. The muscularis mucosa was marked by longitudinally arranged smooth muscle fibers towards the side of the submucosa and vertically arranged smooth muscle fiber strands on the side of the lamina Propria. The villi of the duodenum were lined by simple columnar epithelium. The columnar cells had elongated nuclei (Fig. 1B). The epithelium comprised of multiple cell types i.e. the chief cells, goblet cells and the enterochromaffin cells. Few polymorphonuclear cells were also observed at places in mucosa. The average length of villi was 1575.33 $\mu \mathrm{m}$ and average depth of crypt was $1405.34 \mu \mathrm{m}$ (Table 1) shows normal morphology of duodenum which was visible in the Fig 1(A). Ahmed et al. (2020) concluded that broilers consuming soybean meal (SBM) diets had $22 \%$ longer villi, $10 \%$ deeper crypts, and $30 \%$ greater $\mathrm{VH}$ to crypt depth ratio (VCR) compared to those fed canola meal (CM). The broilers fed $110 \%$ d-Thr diets had $9 \%$ lower crypt depth (CD) and 15\% greater VCR compared with those fed diets containing NRC recommended levels. 
Lining mucosa and epithelium $\left(\mathrm{T}_{3}\right)$ were like the control groups. The average height of the villi was $1413.13 \mu \mathrm{m}$ and depth of the crypt was $1089.71 \mu \mathrm{m}$ (Table 1) showed non-significant difference from control group which can be seen in Fig. 2(A). The number of polymorphonuclear cells was visibly similar in number as compared to the control groups (Fig. 2.B).

Lining mucosa and epithelium $\left(\mathrm{T}_{4}\right)$ were like the control groups. The villi were thrown into the mucosa showed finger like projection with more conical apex ,thick body and base (Fig. 3.A) as compared to control group with no significant difference in the villi length was $1647.44 \mu \mathrm{m}$ but differs significantly $(\mathrm{P}<0.05)$ with relation to crypt depth was $1128.80 \mu \mathrm{m}$ (Table 1). The goblet cells were fewer in the epithelial layer.

Lining mucosa and epithelium $\left(\mathrm{T}_{5}\right)$ were similar to the control groups. Fig. 5 (A), suggested longer villi length and decreased crypt depth (Table 1) as compared to other groups fed with RGM@15\%. The villi were with pointed apex and slender body as compared to control group. There was difference in the villi length and crypt depth from the control significantly $(\mathrm{P}<0.05)$. The number of polymorphonuclear cells in mucosa which was visible showed higher number than that of control and other treatment groups. Higher length of villus might be associated with increased the surface area for absorption of nutrients (Xu et al., 2003). Wani et al. (2018) studied that there was no significant effect of different RGM levels on the intestinal morphometryat 21 and 42 days of age. Behera et al. (2018) concluded that supplementation of citrus waste decreased the villi height and crypt depth at higher citrus waste inclusion level. However, supplementation of enzyme didn't showed any significant difference between the groups.
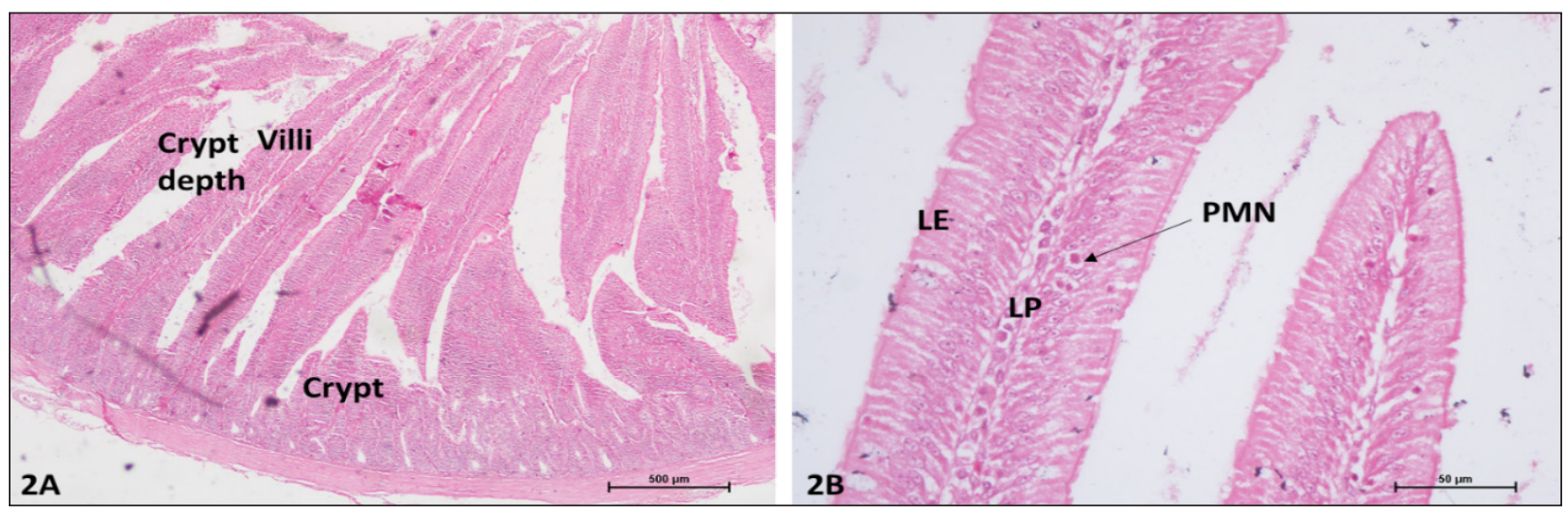

Fig. 2: Paraffin section of duodenum of $\mathrm{T}_{3}$ birds supplemented with $10 \%$ RGM showing duodenal villi, crypt and crypt depth (2A); Lamina epithelialis (LE), polymorphonuclear cells in Lamina propria (LP) (2B); Haematoxylin and eosin: Bar length (A) $500 \mu \mathrm{m}$ and (B) $50 \mu \mathrm{m}$

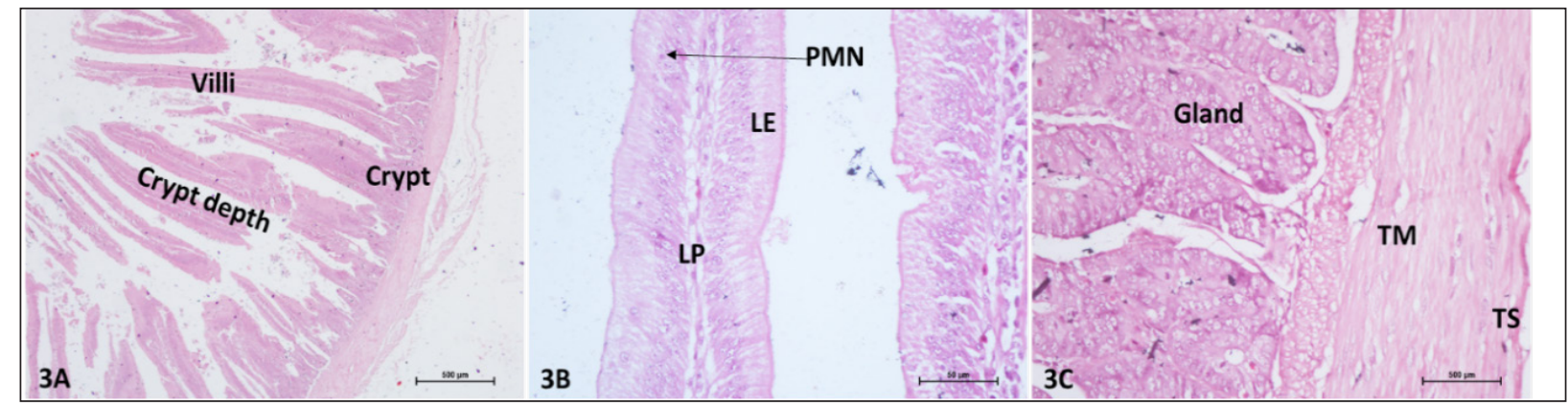

Fig. 3: Paraffin section of duodenum of $\mathrm{T}_{4}$ birds supplemented with $10 \%$ RGM showing duodenal villi, crypt and crypt depth (3A); Lamina epithelialis (LE), polymorphonuclear cells in Lamina propria (LP) (3B); glands in crypt, tunica mucosa (TM) and tunica serosa (TS) (3C); Haematoxylin and eosin: Bar length (A) $500 \mu \mathrm{m}$, (B) $50 \mu \mathrm{m}$ and (C) $500 \mu \mathrm{m}$ 


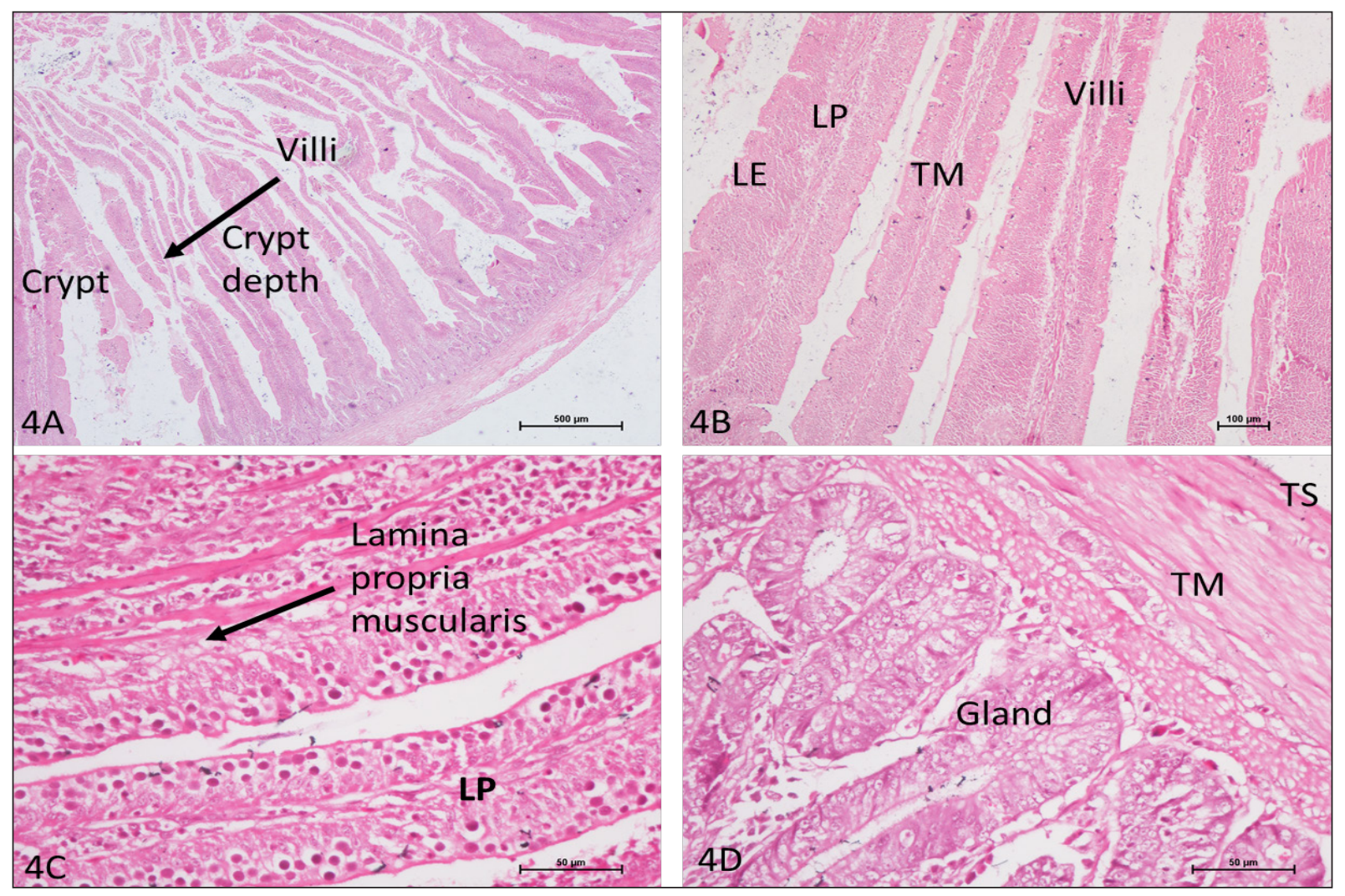

Fig. 4: Paraffin section of duodenum of $\mathrm{T}_{5}$ birds showing duodenal villi, crypt and crypt depth, (4A); Lamina epithelialis (LE), Lamina propria (LP), tunica mucosa (TM) and villi (4B); Lamina propria muscularis in Lamina propria (LP) (4C); glands in crypt, tunica mucosa (TM) and tunica serosa (TS) (4D); Haematoxylin and eosin: Bar length (A) $500 \mu \mathrm{m},(B) 100 \mu \mathrm{m}$, (C) and (D) $50 \mu \mathrm{m}$

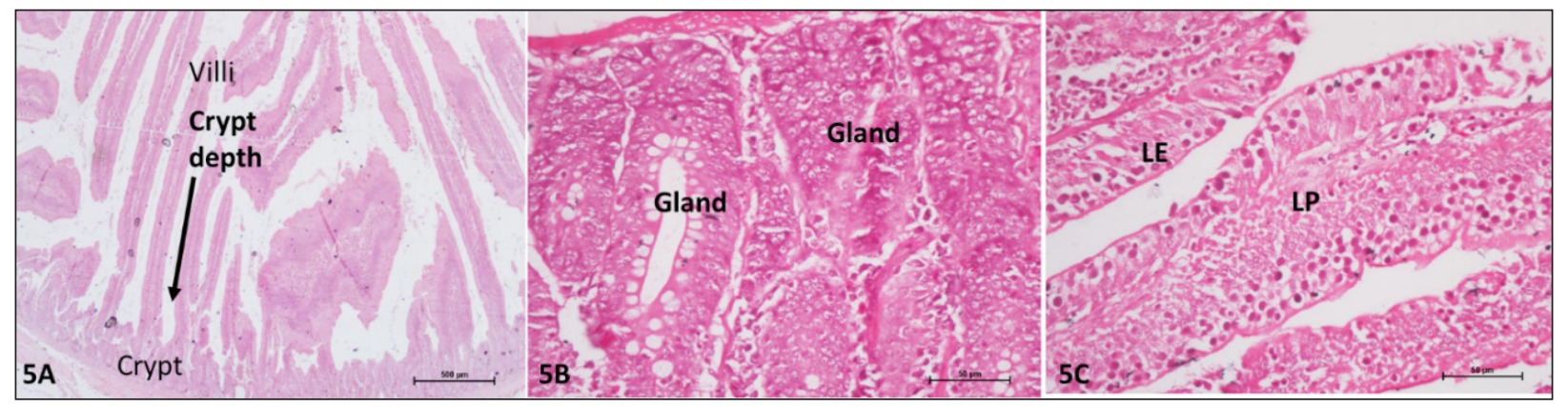

Fig. 5: Paraffin section of duodenum of $T_{6}$ birds showing duodenal villi, crypt and crypt depth, (5A); glands in crypt (5B); Lamina epithelialis (LE), Lamina propria (LP) (5C); Haematoxylin and eosin: Bar length (A) $500 \mu \mathrm{m}$, (B) and (C) $50 \mu \mathrm{m}$

Mucosa of duodenum of fowl $\left(\mathrm{T}_{6}\right)$ fowls was thrown in finger like slender, unbranched longitudinal villi (Fig. 5A). The villi were longer when compared to control group significantly $(\mathrm{P}<0.05)$. The morphology of lamina propria, muscularis mucosa is having same longitudinally arranged smooth muscle fibers towards the side of the submucosa and vertically arranged smooth muscle fibre strands on the side of the lamina Propria like that of control group. The villi of the duodenum were lined by simple columnar epithelium. The columnar cells had elongated nuclei (Fig. 5B). The goblets cells appeared numerous as compared to the control groups. But the amount of polymorphonuclear cell in mucosa was higher in number when compared with control group. The number of polymorphonuclear cells in 
mucosa showed higher number than that of control and suggesting effect of RGM with enzyme supplements in the gut mucosa. It showed that RGM with enzymes in the diet resulted in increased the number of polymorphonuclear cells. Higher number of polymorphonuclear cells in mucosa might be suggestive of some immunomodulative effects of this feed combination in the gut mucosa. Dinani et al. (2019a) reported that villus height (VH) decreased significantly in 20, 25 and 30\% RGM levels but villus depth (VD) and VH/VD did not show any significant difference between control and other dietary treatments. Villus width (VW) also decreased significantly in 20, 25 and 30\% RGM levels. Dinani et al. (2019b) revealed that $12.5 \%$ rDDGS and $15 \%$ RGM level in combination showed significant decrease in villus height and villus width as compared to control.

Qaisrani et al. (2020) studied that in broilers fed the soybean meal compared with those fed the rapeseed meal and maize gluten diets, villus height was increased by $18.2 \%$ and $17.7 \%$, whereas crypt depth was reduced by $15.5 \%$ and $18.1 \%$, and villus height to crypt depth ratio was increased by $29.0 \%$ and $30.9 \%$, respectively. Qaisrani et al. (2020) studied that in broilers fed the soybean meal compared with those fed the rapeseed meal and maize gluten diets, villus height was increased by $18.2 \%$ and $17.7 \%$, whereas crypt depth was reduced by $15.5 \%$ and $18.1 \%$, and villus height to crypt depth ratio was increased by $29.0 \%$ and $30.9 \%$, respectively.

\section{CONCLUSION}

The present study showed the villus height was greater in the duodenum while there was a tendency for increased villus height to crypt depth ratio in the duodenum of broilers supplemented with $15 \%$ rice gluten meal. These results indicated that rice gluten meal enhanced the villus development in the small intestine of broilers.

\section{REFERENCES}

Ahmed, I., Qaisrani, S.N., Azam, F., Pasha, T.N., Bibi, F., Naveed, S. and Murtaza, S. 2020. Interactive effects of threonine levels and protein source on growth performance and carcass traits, gut morphology, ileal digestibility of protein and amino acids, and immunity in broilers. Poult. Sci, 99(1): 280-89.
Behera, D.P., Sethi, A.P.S., Pathak, D., Chahal, U. and Wadhwa M. 2018. Effect of different levels of citrus waste (Kinnow $s p$.) on duodenal morphology of broiler birds without and with cocktail of enzymes. Indian J. Anim. Res., 8(5): 775782

Bhatt, R.S. and Sharma, S.R. 2001. Nutrient utilization and growth performance of broiler rabbits fed oat plant meal and tall fescue hay. Asian Australas J. Anim. Scialas., 14: 122832.

Dinani, O.P., Tyagi, P.K., Mandal, A.B., Tyagi, P.K. and Dutta, N. 2019a. Evaluation of feeding value of rice based distillers dried grains with solubles (DDGS) for broiler chickens. Indian J. Anim. Res., 53(7): 901-06.

Dinani, O.P., Tyagi, P.K., Mandal, A.B., Tyagi, P.K., Kumar, F. and Tiwari, S.P. 2019b. Effect of Feeding rice based distillers dried grains solubles with and without Enzymes on Haematobiochemical profile of Broiler Chickens. J. Anim. Res., 9(1): $35-43$.

Giannenas, I., Bonos, E., Anestis, V., Filioussis, G., Papanastasiou, D.K., Bartzanas, T., Papaioannou, N., Tzora, A. and Skoufos, I. 2017. Effects of protease addition and replacement of soybean meal by corn gluten meal on the growth of broilers and on the environmental performances of a broiler production system in Greece. PloS One., 12(1).

Govt. of India, Ministry of Agriculture \& Farmers Welfare. 2018. Area, production and yield of principal crops. In: Agricultural Statistics at a glance 2018. Govt. of India Controller of Publication: 74-75.

Kumar, R., Thakur, S.S. and Mahesh, M.S. 2016. Rice gluten meal as an alternative by-product feed for growing dairy calves. Trop. Anim. Health Prod., (3): 619-24.

Loar, R.E., Moritz, J.S., Donaldson, J.R. and Corzo, A. 2010. Effects of feeding distillers dried grains with soluble to broilers from 0 to 28 days posthatch on broiler performance, feed manufacturing efficiency, and selected intestinal characteristics. Poult.Sci., 89(10): 2242-50.

Long, S.F., He, T.F., Wu, D., Yang, M. and Piao, X.S. 2020. Forsythia suspensa extract enhances performance via the improvement of nutrient digestibility, antioxidant status, antiinflammatory function and gut morphology in broilers. Poult. Sci., 99(9): 4217-26.

Metwally, A. and Farahat, M. 2015. Nutritive value and feeding of rice gluten meal in broiler chickens. Res. Opin. In. Anim. Vet. Sci., 5(11): 443-51.

Nasrin, M., Siddiqi, M.N.H., Masum, M.A. and Wares, M.A. 2012. Gross and histological studies of digestive tract of broilers during postnatal growth and development. $J$. Bangladesh Agri. Univ., 10(1): 69-77. 
Pathak, D. and Bansal, N. 2012. Histomorphology of the endometrial gland of buffalo. Indian Vet. J., 89(9): 25.

Qaisrani, S.N., Van Krimpen, M.M., Verstegen, M.W.A., Hendriks, W.H. and Kwakkel, R.P. 2020. Effects of three major protein sources on performance, gut morphology and fermentation characteristics in broilers. Br. Poul. Sci., 61(1): 43-50.

Rana, J., Dhote, B.S., Ambwani, T.K. and Patel, S.K. 2016. Histochemical studies on small intestine of Uttara fowl. Int J. Environ. Sci. T., 5(3): 1181-88.

Schindelin, J., Arganda-Carreras, I., Frise, E., Kaynig, V., Longair, M., Pietzsch, T., Preibisch, S., Rueden, C., Saalfeld, S., Schmid, B., Tinevez, J.Y., White, D.J., Hartenstein, V., Eliceiri, K., Tomancak, P. and Cardona, A. 2012. Fiji: an open-source platform for biological-image analysis. Nat. Methods., 9: 676-82.
Sherazi, T.H., Alam, M.Z., Gilani, A.H. and Nawaz, H. 1995. Graded replacement of fish meal with rice protein meal in broiler ration. Pak. J. of Agric. Sci., 32: (2-3).

Wani, M.A., Tyagi, P.K., Mir, N.A., Hazarika, R., Sheikh, S.A., Tyagi, P.K., Dinani, O.P. and Mandal, A.B. 2018. Feeding value of rice gluten meal as an alternate protein source in broiler chickens. Turk. J. Vet. Anim. Sci., 42(5): 473-79.

Xu, Z.R., Hu, C.H., Xia, M.S., Zhan, X.A. and Wang, M.Q. 2003. Effects of dietary fructo-oligosaccharide on digestive enzyme activities, intestinal microflora and morphology of male broilers. Poult. Sci., 82: 648-654.

Youssef, A.W., El-Azeem, N.A., El-Daly, E.F. and El-Monairy, M.M. 2013. The Impact of Feeding Graded Levels of Distillers Dried Grains with Solubles (DDGS) on Broiler Performance, Hematological and Histological Parameters. Asian J. Poult. Sci., 7(2): 41-54. 
